\title{
The Effect of Service Quality Dimensions on Customers' Loyalty through Customer Satisfaction in Jordanian Islamic Bank
}

\author{
Ayed Al Muala ${ }^{1}$ \\ ${ }^{1}$ Faculty of Economics and Administrative Sciences, Zarqa University, Jordan \\ Correspondence: Ayed Al Muala, Faculty of Economics and Administrative Sciences, Zarqa University, Jordan. \\ E-mail: aied_muala@yahoo.com
}

Received: June 7, 2016 Accepted: August 8, $2016 \quad$ Online Published: November 30, 2016

doi:10.5539/ijms.v8n6p141 URL: http://dx.doi.org/10.5539/ijms.v8n6p141

This research is funded by deanship scientific research and graduate studies in Zarqa University, Jordan.

\begin{abstract}
The goal of this paper is to investigate the effect of banking Service Quality Dimensions on customers' satisfaction, and customers' loyalty. The dimensions include tangibility, reliability, empathy, responsiveness, and assurance. The researcher used a questionnaire survey to elicit data from the participants of the study. The sample included 250 questionnaires. They were distributed over a number of Islamic Bank customers in Jordan, particularly in the capital city "Amman". The results of the study showed that there is a positive effect of Tangibility, Reliability, Empathy, Responsiveness, Assurance, on customer satisfaction toward customers' loyalty. This has confirmed the Hypothesis of the study (H1, H2, H3, H4, and H6) in terms of being significantly and positively related to customers' satisfaction and loyalty. On the other hand, one hypothesis is insignificant impact which is H5.
\end{abstract}

Keywords: service quality dimensions, customer satisfaction, loyalty, Jordan

\section{Introduction}

In the past two decades, general interests into service quality in research fields showed various researches on service quality which has been taken a place. At that time, manifested centrifugal relation among quality of customer services, performance improvement and organizational competitiveness have been studied. This relation clearly showed that the improvement of customer services will lead in its turn to an improvement in the performance and competitiveness (Douglas \& Connor, 2003; Rosen, Karwan, \& Scribner, 2003). Certain standards and indicators of customer satisfaction and service quality are used by service units' administrators to value customers' needs by the institution. Service organizations consider service quality as substantial tool to keep their competitiveness in the marketplace. For instance, financial services that offered by different banks are considered as an important competitive tool by using distinguished products (Logasvathi \& Haitham, 2015). That is, customers might get attracted by good quality services that banks offer. On other words, structural change the improvement of banks' plans in order to make different activities which empower them to be more competitive in market place (Angur, Nataraajan, \& JrJaherea, 1999). Furthermore, banks have an essential role in economic and financial growth in Jordan. Apparently, the growth of Jordanian economy is greatly influenced by effective banking system. Furthermore, banks experience many challenges in their sectors due to the changing of customers' requirements and to overcome these challenges, it's important for banks to use the most current information technology to advance globally (Lau, Cheung, Lam, \& Chu, 2013).

Moreover, banks are responsible to provide best quality services for customers to ensure permanent competitive advantages. Service providers face many challenges to value the quality of services because of business sector's inappropriate service quality. The challenges of valuing the quality of services result from diversity, intangibility and the separation difficulty (Saghier \& Nathan, 2013). In this regard, the service demands autonomous structure to measure and explain the quality. One of the common and largely used model to measure the quality service in the sectors is, the service quality model designed by Parasuraman, Zeithaml and Berry (1985; 1988). In addition, research has been done on service quality and customer satisfaction. In opposition, there is a scarcity of research 
in the present time on the setting of retail banking to consider the effects of the service features' performance against the satisfaction of bank customers.

\section{Literature Review}

\subsection{Customers' Satisfaction and Loyalty}

The strategic objective which is the basis of the relationship marketing approach consists of achieving customer loyalty. A comprehensive definition of bank loyalty views the construct as "the biased (i.e. non random) behavioural response (i.e. revisit), expressed overtime by the decision-making unit with respect to one bank out of a set of banks, which is a function of psychological (decision-making and evaluative) process resulting in brand commitment" (Bloemer, de Ruyter, \& Peeters, 1998). An important statement, which has to be remarked, is the distinction between customer loyalty and customer retention.

According to Dick and Basu, loyalty is a complex construction, which comprises both psychological and behavioural components; different types of loyalty are supposed to form a combination of repeated purchasing and relative attitude towards business firms (Dick \& Basu, 1994). According to Inamullah (2012) "Customer loyalty is the willingness of a consumer to purchase the same product and keep the same profitable relationship with a particular company". Therefore, customer loyalty can be defined in terms of customer behavior, which will be equivalent with customer retention, and in terms of attitudes such as: number of purchases made by the customer, the frequency of purchasing, the percentage from the total spending made by a customer for a particular service or product, with regard to a particular organization and the possibility of buying by the customer.

According to Kotler, Armstrong, Saunders, and Wong (2002), customer satisfaction can be defined in different ways, but generally he emphasized that it is related to customer evaluation of experience and expectancy. Customer satisfaction should be taken into account to assure customer loyalty towards service supplies of any organization. In banks, customers care about the level of services which were given to decide whether they are satisfied with such services after using them. Customers' satisfactions get higher when they have to offer minimal payment and get maximum of profit and usage.

On the other hand, a study was done in the Malaysian retail banking industries by Lo, Osman, Ramayah and Rahim (2010) stated that assurance and empathy possessed great effect on the satisfaction of bank customers. More studies done by Arasli, Smadi and Katircioglu (2005) showed that reliability had the highest influence on customer satisfaction. It also showed that reliability affected customers' satisfaction greatly. Finally, Lau et al. (2013) and Saghier \& Nathan (2013) claimed that due to the fact that loyalty is related to customer satisfaction, banks performed new affective strategies to improve the quality of service satisfaction and loyalty (Awan, Bukhari, \& Anam, 2011). To conclude, Lau et al. (2013) and Saghier \& Nathan (2013) have identified the dimensions of service quality as the predecessors of customer satisfaction. Many studies have investigated service quality in the retail banking sector in Jordan. Due to the fact that loyalty is related to customer satisfaction, banks performed new affective strategies to achieve satisfactory service quality and loyalty (Awan et al., 2011).

\subsection{Service Quality Dimensions}

Service quality has become the focus of attention for many academic researchers because of the serious Competition in the marketplace and has been identified as the main key in maintaining good benefit and trustful connection to achieve customers' satisfaction (Zeithaml, 2000). According to Ueno (2010), he considered the service quality gaps model is the conceptualization of service quality as the gap between expected service and perceived service. Furthermore, the importance of service quality can be represented in the service industries and service providers should understand the concept of service quality to show the differentiation of products for their customers. Many studies have been discussing service quality by developing new models and theories to address the importance of implementation and large extent of good quality services. Moreover, the quality of the services has been investigated by many researchers in different manners. Eshghi, Roy and Ganguli (2008) defined service quality as an overall evaluation by customer service; while other researchers stated that customer service is an expansion to which service fulfill customer's expectations and needs. In addition, service quality has been taken as the level of variation amongst in relation to the expectations of the customers concerning the services as well as their understanding of the implementation of those services (Parasuraman, Berry, \& Zeithaml, 1994).

Tangibles: as the quality of services including the companies' structure of several elements, such as company representatives, physical facilities, materials, tools and communication materials. According to Fitzsimmons \& Fitzsimmons (2001), consideration is given for details and information by some of the providers resulted in clear 
appearance of physical environmental conditions. Tangibles summarized as physical affirmation of the service (Davis, Acquilano, \& Chase, 2003). Precisely, Parasuraman et al. (1985) state that tangibility seems to be physical facilities, tools, personnel and registered materials. Finally, the recent research detected that the services of the banks provided for the customers tangibles valued by 4 items of the total 22 tangibles dimension of service quality.

Reliability: in service quality depends on dealing with the issues of customer services; provide these services at the first time and on time and keep a record of no errors. Reliability, as a result, reliability has been defined as the essential element in traditional service (Parasuraman et al., 1988). Reliability can be formed of right order completion, precise records; precise quote, accurate bills, precise outcomes and credibility in the services. Yang and Fang (2004) indicated that reliability is the most important factor in banking services. A study done by Parasuraman et al. (1985) stated that service quality was performed in four different companies, those companies include banks, maintenance service, companies credit card, and companies and telecommunication companies. According to Parasuraman et al. (1985, p. 24) reliability is higher in these four companies comparing to some of the values which are related to the important dimensions. It relates to the "ability to perform the promised service dependably and accurately" (Parasuraman et al., 1988, p. 23). This paper is concerned to discuss the reliability as a possibility and capability of providing banking services at particular Jordanian banks to accomplish the targeted services as expected by the particular Jordanian bank headquarters. Out of 22 items of service quality, 5 items of reliability dimension are used to measure this issue.

Responsiveness: as a SERVQUAL Dimension Responsiveness is referred to by (Parasuraman et al., 1988) as the potentiality to assist bank customers to afford quality services. On the other side, Johnston (1997) defined responsiveness as quickness and timeliness of the delivery service. This contains operating quickness and abilities to react immediately to the demands of the customer. More specifically, it is looked at the desire and preparedness of workers to offer quality service. It relates to the services timeliness (Parasuraman et al., 1985). It also consists observing the needs and demands of customers, easy and fast processing time, taking care of customers individually by the staff, solving problems and customers' safety (Kumar, Mani, Mahalingam, \& Vanjikovan, 2010). In conclusion, responsiveness in this paper refers to the preparedness of the providers of the bank services at a particular bank headquarters, to offer services on time as expected by a particular Jordanian band headquarters' banking customers. Four items out of the 22 items of responsiveness dimension service quality are used to measure this.

Empathy: is the individual attention and looking after clients by the company staff. It also consists of giving consideration to staffs who perceive the clients' demands and facilities during working hours (Parasuraman et al., 1985).

Assurance: confidence and trust when dealing with the organization. These feelings reflect employees experience and knowledge and their capability to be confident in themselves and build a confidence in the customers themselves. According to (Blery, Batistatos, Papastratou, Perifanos, Remoundaki, \& Retsina, 2009), assurance can be developed by the level of information, knowledge and kind treatment by the employees in offering the services and their capability to build trust and confidence in clients. Thus, model of study as shown in Figure 1, has dimensions of service quality as independent variables and customer satisfaction as dependent variable.

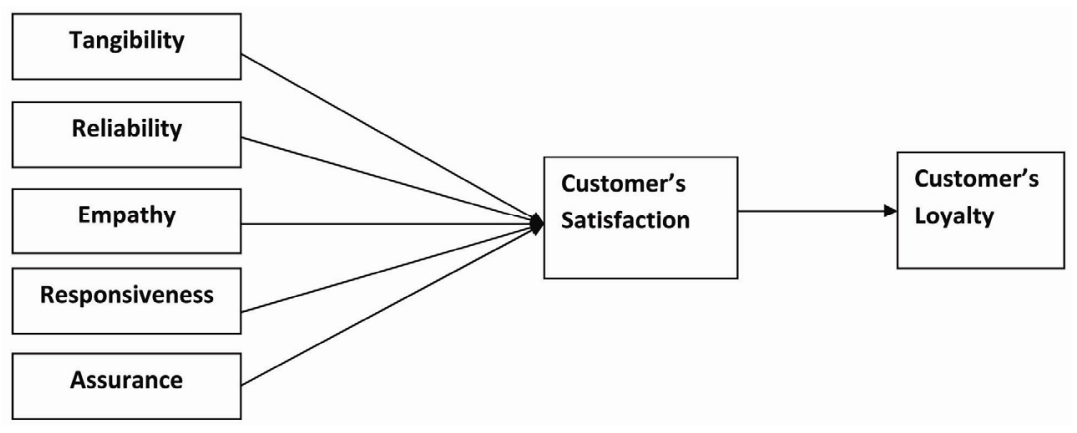

Figure 1. Research conceptual model 


\section{Hypotheses Formulation}

The current study is based on six hypotheses as following:

H1 Customer satisfaction is positively with Customer Loyalty

H2 Tangibility is related positively with Customer Satisfaction.

H3 Reliability is related positively with Customer Satisfaction.

H4 Empathy is related positively with Customer Satisfaction.

H5 Responsiveness is related positively with Customer Satisfaction.

H6 Assurance is related positively with Customer Satisfaction.

\section{Research Methodology}

This section will address the following issues that Pertains to research design such as population; sample size, sampling method, hypothesis of the research, questionnaires design, analysis method and result of reliability. The population of the study consists of all Jordanian Islamic Bank at Amman city. About 250 questionnaires were distributed to Jordanian Islamic Bank customers' at Amman city, however; only 200 questionnaires obtained have valid responses and were used for data analysis in this research paper. According to Sekaran (2003), a total of 200 responses were usable and used for subsequent analysis, giving a response rate of $80 \%$ using the 5-point Likert-scale for all responses with $(1=$ strongly disagree, $2=$ disagree, $3=$ undecided, $4=$ agree, 5 = strongly agree). The questionnaire is divided into four parts: part (1) demographic variables (12) items; part (2) service quality dimensions (22) items were adapted from Parasuraman et al. (1994); part (3) customer satisfaction (5) items adopted from Al Muala and Al Qurneh (2012). Finally, part (4) customer loyalty (5) items adapted from Al Muala and Al Qurneh (2012). To conclude, a comprehensive sampling, the researcher used convenience sampling procedures as a common form of sampling design in social science research. Mohr and Spekman (1994) provide researchers with an acceptable database to use statistical inference techniques. This approach to sampling design is also applicable in services marketing.

\section{Results}

\subsection{Reliability Test}

The reliabilities for the variables were calculated and all concurred with Nunnally's (1978) minimum threshold of 0.70. Table 1 lists the Cronbach's Alpha (coefficient alpha) of each factor. All the factors show a high degree of reliability. Table 1 shows that there were five independent factors and one dependent factor of customers' satisfaction that was examined by the researcher.

Table 1. Reliability results

\begin{tabular}{lll}
\hline Variables & Number of Item & Cronbach Alpha \\
\hline Customer Loyalty & 5 & 0.80 \\
Tangibility & 5 & 0.85 \\
Reliability & 5 & 0.87 \\
Empathy & 4 & 0.86 \\
Responsiveness & 4 & 0.81 \\
Assurance & 4 & 0.85 \\
Customers' Satisfaction & 4 & 0.85 \\
TOTAL & 35 & \\
\hline
\end{tabular}

\subsection{Demographic Variables}

The respondents' gender is shown that the male respondents were (54.2\%) than female (45.8\%). The respondents belongs to the age group were between 26 years old and 35 years old $(48.2 \%)$. Respondents who possess a bachelor degree were (26.6) or diploma was (18.3\%). Moreover, $14 \%$ of the respondents were from the group with incomes less than 300 JD and 301-500 JD (13.4\%).

\subsection{Hypothesis Test}

The results of Hypothesis (1) showed that the data indicate tangibility dimension value is significantly and positively affect customers' satisfaction of the total sample (Beta $=.109, \mathrm{p}=.036)$. The data shows that reliability 
dimension is significantly and positively affect to customers' satisfaction of the total sample (Beta $=.113$, $\mathrm{p}=.025)$.

Therefore, the results support five Hypothesis of the study (H1, H2, H3, H4 and H6). While, one hypothesis was rejected which is H5. The data indicate that most of the findings of Hypothesis are significantly and positively relate to customers' satisfaction and customer loyalty.

Table 2. Hypothesis results

\begin{tabular}{llllll}
\hline Variable Name & B & Std. Error & Beta & t & sig \\
\hline H1 & .645 & .123 & .10 & 4.675 & .000 \\
H2 & .109 & .052 & .110 & 2.105 & .036 \\
H3 & .113 & .059 & .113 & 2.920 & .025 \\
H4 & .170 & .051 & .173 & 3.305 & .001 \\
H5 & .016 & .053 & .015 & .295 & .465 \\
H6 & .383 & .044 & .411 & 8.646 & .000 \\
\hline
\end{tabular}

\section{Conclusions}

This research examined the effect of banking service quality dimensions (Tangibility, Reliability, Empathy, Responsiveness, Assurance) on customers' satisfaction and customer loyalty at Amman city, after collecting and analyzing the data using SPSS, regression analysis showed that, all the dimensions have their own effects on customers' satisfaction. Among the independent variables, Assurance posses the highest effect on customers' satisfaction. Based on these results, the researcher recommend that Jordanian Islamic Bank should focus more on Assurance and responsiveness dimensions to improve service quality in order to satisfy their customers' more as well as to enhance their buying decision of the bank service. In addition, customer satisfaction has a significant impact on customer loyalty.

\section{References}

Al Muala, A. M., \& Al Qurneh, M. (2012). Assessing the Relationship between Marketing Mix and Loyalty through Tourists Satisfaction in Jordan Curative Tourism. American Academic \& Scholarly Research Journal, 4(2).

Angur, M., Nataraajan, R., \& JrJaherea, J. (1999). Service quality in the banking industry: An assessment of developing economy. International Journal of bank Marketing, 17(3), 116-125.

Arasli, H., Smadi, S., \& Katircioglu, S. T. (2005). Customer service quality in the Greek Cypriot banking industry. Managing Service Quality: An International Journal, 15(1), 41-56.

Awan, H, M., Bukhari, K. S., \& Anam, I. (2011). Service quality and customer satisfaction in the banking sector A comparative study of conventional and Islamic banks in Pakistan. Journal of Islamic Marketing, 2(3), 203-224. https://doi.org/10.1108/17590831111164750

Blery, E., Batistatos, N., Papastratou, E., Perifanos, I., Remoundaki, G., \& Retsina, M. (2009). Service quality and customer retention in mobile telephony. Journal of Targeting, Measurement and Analysis for Marketing, 17(1), 27-37.

Bloemer, J., de Ruyter, K., \& Peeters, P. (1998). Investigating drivers of bank loyalty: the complex relationship between image, service quality and satisfaction. International Journal of Bank Marketing, 16(7), 276-286.

Davis, M. M., Acquilano, N. J., \& Chase, R. B. (2003). Fundamentals of Operations Management. New York: McGraw Hill/Irwin.

Dick, A. S., \& Basu, K. (1994). Customer loyalty: Toward an integrated conceptual framework. Journal of the Academy of Marketing Science, 22(2), 99-113.

Douglas, L., \& Connor, R. (2003). Attitudes to service quality-the expectations gap. Nutrition and Food Science, 33, 165-172.

Fitzsimmons, J. A., \& Fitzsimmons, M. J. (2001). Service Management: operations, strategy, and information technology. New York: McGraw Hill Inc.

Inamullah, K. (2012). Impact of Customers Satisfaction and Customers Retention on Customer Loyalty. International Journal of Scientific \& Technology Research, 1(2), 106-110. 
Johnston, R. (1997). Identifying the critical determinants of service quality in retail banking: importance and effects. The International Journal of Bank Marketing, 15(4), 111-119.

Kotler, P., Armstrong, G., Saunders, J., \& Wong, V. (2002). Principle of Marketing (3rd ed.). Pretence Hall.

Kumar, S. A., Mani, B. T., Mahalingam, S., \& Vanjikovan, M. (2010). Influence of Service Quality on Attitudinal Loyalty in Private Retail Banking: An Empirical Study. IUP Journal of Management Research, 9(4), 21-38.

Lau, M., Cheung, R., Lam, A., \& Chu, Y. (2013). Measuring service quality in the banking industry: a Hong Kong based study. Contemporary Management Research, 9(3), 263-283. https://doi.org/10.7903/cmr.11060

Lo, L. K., Osman, M., Ramayah, T., \& Rahim, M. (2010). The impact of service quality on customer loyalty: A study of banks in Penang, Malaysia. International Journal of Marketing Studies, 2(2), 57-66.

Logasvathi, M., \& Haitham, A. (2015). Study of customer satisfaction in the banking sector in Libya. Journal of Economics, Business and Management, 3(7).

Mohr, J., \& Spekman, R. (1994). Characteristics of Partnership Success: Partnership Attributes, Communication Behavior, and Conflict Resolution Techniques. Strategic Management Journal, 15, 135-152. https://doi.org/10.1002/smj.4250150205

Nunnally, J. L. (1978). Psychometric theory (2nd ed.). New York: McGraw-Hill.

Parasuraman, A., Berry, L., \& Zeithaml, V. (1994). Reassessment of expectations as a comparison standard in measuring SQ: implications for future research. Journal of Marketing, 58, 111-124. https://doi.org/10.2307/1252255

Parasuraman, A., Zeithaml, V. A., \& Berry, L. L. (1985). A conceptual model of service quality and its implications for future research. Journal of Marketing, 49, 41-50. https://doi.org/10.2307/1251430

Parasuraman, A., Zeithaml, V. A., \& Berry, L. L. (1988). SERVQUAL: A multi-item scale for measuring consumer perceptions of service quality. Journal of Retailing, 64, 12-40.

Rosen, L. D., Karwan, K., \& Scribner, L. (2003). Service quality measurement and the disconfirmation model: taking care in interpretation. Total Quality Management, 14, 3-14. https://doi.org/10.1080/14783360309703

Saghier, N., \& Nathan, D. (2013). Service quality dimensions and customer's satisfactions of banks in Egypt. 20th international business research conference, 4-5 April 2013, Dubai, UAE.

Sekaran, U. (2003). Research methods for business (4th ed.). Hoboken, NJ: John Wiley \& Sons.

Ueno, A. (2010). What are the fundamental features supporting service quality? Journal of Services Marketing, 24(1), 74-86.

Yang, Z., \& Fang, X. (2004). Online service quality dimensions and their relationships with satisfaction: A content analysis of customer reviews of securities brokerage services. International Journal of Service Industry Management, 15(3), 302-326. https://doi.org/10.1108/09564230410540953

Zeithaml, V. (2000). Service quality, profitability and the economic worth of customers: What we know and what we need to learn. Journal of the Academy of Marketing Science, 28(1), 67-85.

\section{Copyrights}

Copyright for this article is retained by the author, with first publication rights granted to the journal.

This is an open-access article distributed under the terms and conditions of the Creative Commons Attribution license (http://creativecommons.org/licenses/by/4.0/). 